\title{
2,3-Dihydroxy-6-Nitro-7-Sulfamoyl-Benzo(f)Quinoxaline Reduces Glial Loss and Acute White Matter Pathology after Experimental Spinal Cord Contusion
}

\author{
Lisa J. Rosenberg, Yang D. Teng, and Jean R. Wrathall \\ Neurobiology Division, Department of Cell Biology, Georgetown University, Washington, DC 20007
}

\begin{abstract}
Focal microinjection of 2,3-dihyro-6-nitro-7-sulfamoylbenzo( $f$ )quinoxaline (NBQX), an antagonist of the AMPA/kainate subclass of glutamate receptors, reduces neurological deficits and tissue loss after spinal cord injury. Dose-dependent sparing of white matter is seen at 1 month after injury that is correlated to the dose-related reduction in chronic functional deficits. To determine whether NBQX exerts an acute effect on white matter pathology, female, adult Spague Dawley rats were subjected to a standardized weight drop contusion at T-8 (10 $\mathrm{gm} \times 2.5 \mathrm{~cm})$ and NBQX (15 nmol) or vehicle (VEH) solution focally injected into the injury site 15 min later. At 4 and $24 \mathrm{hr}$, tissue from the injury epicenter was processed for light and electron microscopy, and the histopathology of ventromedial white matter was compared. The axonal injury index, a quan-
\end{abstract}

titative representation of axoplasmic and myelinic pathologies, was significantly lower in the NBQX group at $4 \mathrm{hr}(2.7 \pm 0.24$, mean $\pm \mathrm{SE})$ and $24 \mathrm{hr}(1.4 \pm 0.19)$ than in VEH controls $(3.8 \pm$ 0.33 and $2.1 \pm 0.20$, respectively). Counts of glial cell nuclei indicated a loss of at least $60 \%$ at 4 and $24 \mathrm{hr}$ after injury in the VEH group compared with uninjured controls. NBQX treatment reduced this glial loss by half. Immunohistochemistry revealed that the spared glia were primarily oligodendrocytes. Thus, the chronic effects of NBQX in reducing white matter loss after spinal cord injury appear to be attributable to the reduction of acute pathology and may be mediated through the protection of glia, particularly oligodendrocytes.

Key words: spinal cord injury; NBQX; CC1; oligodendrocytes; astrocytes; microglia; white matter
Traumatic injury to the spinal cord produces loss of gray matter and white matter (WM) that leads to permanent neurological deficits. Most injuries are the result of spinal cord contusion, i.e., a bruising caused by the impact of vertebral bone onto the dura after rapid flexion-extension of the spinal column. Approximately half are initially classified as "incomplete," in that some function can be detected below the injury site (Bracken et al., 1990). Experimental models of such incomplete contusion spinal cord injury (SCI) have been developed to investigate the basic pathophysiological mechanisms involved and to test potential therapeutic approaches to mitigate the long-term neurological consequences. From studies of such models, it has become clear that the effects of the initial mechanical destruction of tissue are exacerbated by physiological and biochemical alterations that produce "secondary injury" (Young, 1993; Tator and Fehlings, 1991).

One important component of secondary injury is the elevation of extracellular excitatory amino acids (Panter, et al., 1990; Liu et al., 1991) to levels known to be toxic to neurons (Choi et al., 1987; Choi and Rothman, 1990). Antagonists of both the NMDA and AMPA/kainate subclasses of glutamate receptors, administered after experimental SCI, have been shown to reduce chronic neurological impairment (Faden et al., 1988; Gomez-Pinilla, et al., 1989; Wrathall et al., 1992a, 1994). The highly selective AMPA/kainate receptor antagonist NBQX (Sheardown et al.,

Received Aug. 6, 1998; revised Oct. 14, 1998; accepted Oct. 21, 1998.

This work was supported by National Institutes of Health Grant RO1 NS35647. Initial support for L.J.R. was provided by the National Institutes of Health Training Grant T32 HD07459. We thank Hai Ning Dai and Sadia Aden for preparation of ultramicrotome and cryostat sections.

Correspondence should be addressed to Dr. Jean R. Wrathall, Department of Cell Biology, Georgetown University, 3900 Reservoir Road, Washington, DC 20007.

Copyright (C) 1998 Society for Neuroscience $\quad 0270-6474 / 98 / 190464-12 \$ 05.00 / 0$
1990) improves functional outcome after SCI when given by focal microinjection into the injury site (Wrathall et al., 1992, 1994) or intravenously (Wrathall et al., 1996) at 15 min after injury and even when focal administration is delayed until $4 \mathrm{hr}$ after injury (Wrathall et al., 1997). Focal injection of NBQX 15 min after injury produces dose-dependent sparing of both gray matter and W M chronically at 1 month after SCI (Wrathall et al., 1994). With the optimal dose of NBQX (15 nmol), residual WM at the injury epicenter is doubled. We hypothesized that NBQX might be conveying protection to WM through a mechanism involving AMPA/kainate receptors present on glia (Bettler and Mulle, 1995; Agrawal and Fehlings, 1997; Garcia-Barcina and Matute, 1998; McDonald et al., 1998) and/or glial precursor cells.

Recently, we reported an assay to evaluate acute WM pathology after experimental spinal cord contusion (Rosenberg and Wrathall, 1997). Tissue at the injury epicenter is processed for electron microscopy and pathology in the ventromedial WM evaluated. Overall pathology is represented as an axonal injury index (AII) based on quantification of axoplasmic and myelin pathologies as well as incidence of abnormal periaxonal space. In the current study, we have used this assay to determine whether NBQX administered at 15 min after injury reduces acute WM pathology at 4 and $24 \mathrm{hr}$. In addition, we quantified the numbers and subtypes of glia in the ventromedial WM region in control and NBQX-treated groups. The results demonstrate that NBQX treatment significantly reduces acute WM pathology and suggest that it may do so through mitigating the acute loss of glia, particularly oligodendrocytes, after SCI.

\section{MATERIALS AND METHODS}

$S C I$. Injury was produced with a well characterized contusion weight drop model of SCI (Gale et al., 1985; Wrathall et al., 1985; Panjabi and 
Wrathall, 1988; Raines et al., 1988; Noble and Wrathall, 1989). Female Spague Dawley rats $(225-250 \mathrm{gm})$ were anesthetized with $4 \%$ chloral hydrate $(360 \mathrm{mg} / \mathrm{kg}$, i.p.). A laminectomy was performed at T-8 generating an opening $\sim 2.8 \mathrm{~mm}$ in diameter. The rats were stabilized with the use of angled Allis clamps attached at the seventh and ninth spinous processes. A plastic impounder with a diameter of $2.4 \mathrm{~mm}$ was lowered onto the exposed dura, and a $10 \mathrm{gm}$ weight was dropped onto the impounder from a height of $2.5 \mathrm{~cm}$. After surgery, rats were kept on absorbent bedding with unrestricted access to food and water. Manual expression of the bladder was performed twice daily. No prophylactic antibiotics were used in this study.

Behavioral testing. All rats kept for $24 \mathrm{hr}$ after injury were evaluated for functional deficits before killing. Uninjured rats were tested to ensure they were free of any neurological dysfunction. Rats killed at $4 \mathrm{hr}$ could not be tested because of the lingering effects of the anesthesia.

A battery of tests designed to assess hindlimb reflexes and coordinated use of hindlimbs was conducted as previously described (Gale et al., 1985; Kerasidis et al., 1987). Overall hindlimb deficit was estimated with a combined behavioral score (CBS) that ranges from 0 (normal) to 100 (no hindlimb function). The CBS is highly correlated to the degree of the initial mechanical injury (Panjabi and Wrathall, 1988) and chronic histopathology (Noble and Wrathall, 1985, 1989). Motor function was also examined with the "BBB" scale of open-field locomotor testing (Basso et al., 1995). Behavior scores with the BBB scale range from 0 (no hindlimb function) to 21 (normal).

Drug application. NBQX (sodium salt) was a gift of Novo Nordish A/S (Malov, Denmark). NBQX was dissolved in deionized water at a concentration of $3 \mathrm{mg} / \mathrm{ml}$ (final $\mathrm{pH} 7.4$ ) and sterilized through a $0.22 \mu \mathrm{m}$ syringe filter (Gelman Sciences, Ann Arbor, MI). Delivery of either NBQX or vehicle [VEH; sterile deionized water adjusted with $\mathrm{NaOH}$ and $\mathrm{NaCl}$ to be equivalent in $\mathrm{pH}$ and osmolarity $(50 \mathrm{mOsm})$ to the NBQX solution] was via microinjection directly into the dorsal white matter through a 33 gauge syringe inserted midline, $1 \mathrm{~mm}$ below the dura (Wrathall et al., 1994). NBQX or VEH was administered starting $15 \mathrm{~min}$ after injury. Delivery rate was $0.21 \mu \mathrm{l} / \mathrm{min}$ for a final volume of $1.68 \mu \mathrm{l}$. The total dose of NBQX delivered was $15 \mathrm{nmol}$.

Assessment of WM pathology. Two studies were performed in which WM pathology was assessed at different time points after SCI. In the first study, 11 rats were injured and treated with either VEH $(n=6)$ or NBQX $(n=5)$. Four additional rats served as uninjured controls. At $4 \mathrm{hr}$ after SCI, the rats were reanesthetized with $4 \%$ chloral hydrate and perfused intracardially with saline followed by fixative ( $2 \%$ glutaraldehyde and $2 \%$ paraformaldehyde in $0.1 \mathrm{M}$ sodium cacodylate, $\mathrm{pH} 7.4$ ). In the second study, five rats in each of the two treatment groups (VEH and NBQX) were injured, treated, and killed at $24 \mathrm{hr}$ after injury as described above. Five additional rats were included as uninjured controls.

Immediately after perfusion, cords were removed from the vertebral column and post-fixed in fresh fixative for at least $12 \mathrm{hr}$. A $2 \mathrm{~cm}$ segment (centered on the epicenter of the lesion) was cut from each cord and embedded in 4\% agar. The agar-embedded tissue blocks were mounted on a tissue chopper stage (Sorvall, Newtown, CT) and cut into $250-\mu \mathrm{m}-$ thick sections. One millimeter of tissue (four sections) was collected at the epicenter and at $1 \mathrm{~mm}$ rostral and caudal to the epicenter from each of the cords, post-fixed for $1 \mathrm{hr}$ in $1 \%$ osmium- $1 \%$ potassium ferricyanide in $0.1 \mathrm{M}$ cacodylate, en bloc stained with $1 \%$ uranyl acetate in maleate buffer, $\mathrm{pH}$ 6.0, and flat-embedded in Spurr resin (Ted Pella, Inc., Redding, CA). One micrometer sections were cut from each tissue block, stained with $1 \%$ toluidine blue, and viewed with light microscopy (LM).

Two blocks representative of the injury at each level (epicenter, +1 and $-1 \mathrm{~mm}$ ) were trimmed to $\sim 1 \mathrm{~mm}^{2}$ of ventromedial WM. Our decision to use ventromedial $\mathrm{WM}$ is based on previous studies that showed in our SCI model that this region is consistently intact at $15 \mathrm{~min}$ after injury and shows evidence of subsequent secondary injury processes (Noble and Wrathall, 1985, 1989; Wrathall et al., 1994, 1998; Rosenberg and Wrathall, 1997; Teng and Wrathall, 1997) that may be reduced with acute therapeutic interventions (Wrathall et al., 1994; Teng and Wrathall, 1997). Thus, the ventromedial region appears to be a suitable area in which to study mechanisms of secondary injury in WM (Rosenberg and Wrathall, 1997).

Ultrathin (70-90 nm) sections were cut and placed on 200 mesh nickel grids (Ted Pella). Sections were viewed with a JEOL (Tokyo, Japan) Jem 1200 EX transmission electron microscope. Electron micrographs $(2000 \times)$ were made of four specific areas of the ventromedial WM (Fig. $1 A)$. The four selected areas were defined by four contiguous $(2 \times 2)$ grid squares based on the 200 mesh grids on which the tissue sections were
Table 1. Axonal injury index used for quantitative assessment of pathology

\begin{tabular}{lllc}
$\begin{array}{l}\text { Periaxonal } \\
\text { space }(\%)^{a}\end{array}$ & $\begin{array}{l}\text { Axoplasmic } \\
\text { pathology }^{b}\end{array}$ & $\begin{array}{l}\text { Myelin } \\
\text { pathology }\end{array}$ & Total AII \\
\hline$\leq 25$ & & X & 1 \\
$\leq 25$ & X & & 2 \\
$\leq 25$ & X & X & 3 \\
$26-49$ & & & 4 \\
$26-49$ & & X & 5 \\
$26-49$ & X & X & 6 \\
$26-49$ & X & & 7 \\
$50-74$ & X & X & 8 \\
$50-74$ & X & Irrelevant & 9 \\
$\geq 75$ & Necrotic & & 10 \\
& Axoplasm & &
\end{tabular}

Reprinted with permission from Journal of Neurotrauma (Rosenberg and Wrathall, 1997).

${ }^{a}$ Percent of intramyelinic space not filled by axoplasm. Axons with periaxonal spaces $\geq 50 \%$ always demonstrated some form of axoplasmic pathology.

${ }^{b}$ Axoplasmic pathologies included condensed neurofilaments, swollen or dilated or condensed mitochondria, numerous vesicles or vacuoles, membrane fragments, or abnormally organelle-rich axoplasm. Necrotic axoplasm was classified as axoplasm devoid an organized ultrastructure (e.g., mitochondria, neurofilaments, microtubules, or endoplasmic reticulum).

${ }^{c}$ Myelin pathologies included large spaces within the myelin sheaths, unraveling or unwinding of the myelin, whorls of unwound myelin, and collapsed myelin.

viewed and bordered by the ventral most region of the spinal cord and the ventromedial sulcus (for more detail, see Rosenberg and Wrathall, 1997).

AII. The AII allows quantitative assessment of axonal pathology in ventromedial WM. The assay was performed on the electron micrographs $(2000 \times)$ made of the four specific regions of ventromedial WM. Approximately $1600 \mu \mathrm{m}^{2}$ of tissue was represented by each micrograph. Total numbers of axons in each micrograph were counted, and each axon was assigned a numerical value according to the pathology present in the particular axon (Table 1). Calculation of periaxonal spacing was performed using SigmaScan software (SPSS, San Rafael, CA) that allows us to determine the total intramyelinic area and the percent of space present between the inner myelin sheath and axolemma. We have previously shown the degree of spacing generally falls within the ranges outlined in Table 1 (Rosenberg and Wrathall, 1997).

The AII per micrograph was calculated as the sum of the individual axonal pathology scores divided by the total number of axons. The average AII of each group was based on axonal databases ranging from 1298 to 2248 axons.

Glial counts. One micrometer plastic sections of tissue from the epicenter and $1 \mathrm{~mm}$ rostral and caudal to the lesion were examined by LM. Two sections at each level of the spinal cord, separated by a distance of $250 \mu \mathrm{m}$, were examined. An area measuring $\sim 0.5 \times 0.7 \mathrm{~mm}$ of ventromedial WM bordered by the ventral most region of the spinal cord and the ventromedial sulcus was defined on each side of the sulcus (Fig. 1A, box). All glia within this defined area displaying an intact nucleus were counted at $400 \times$ magnification.

Immunocytochemical identification of glia. For the purpose of glia identification, additional rats were injured and injected with either $\operatorname{NBQX}(n=6)$ or $\operatorname{VEH}(n=6)$ as described above. An additional six rats served as uninjured controls. Twenty-four hours after SCI and behavioral testing, the rats were perfused intracardially with saline followed by $4 \%$ paraformaldehyde in PBS, $\mathrm{pH}$ 7.4. The cords were post-fixed for $1 \mathrm{hr}$ in $4 \%$ paraformaldehyde in PBS and then equilibrated in sucrose (10$20 \%$ in PBS) and left overnight at $4^{\circ} \mathrm{C}$ in $20 \%$ sucrose. In each block, three cords (uninjured, VEH, and NBQX-treated) were embedded together in Tissue-Tek O.C.T. Compound (Fisher Scientific, Jessup, MD), and serial cross-sections $(10$ and $20 \mu \mathrm{m})$ were cut with a Jung Frigicut $2800 \mathrm{E}$ cryostat (Leica, Nubloch, Germany). For morphometry, one slide from each millimeter of tissue was stained with luxol blue/hematoxylin and eosin and evaluated to determine the location of the lesion epicenter.

Tissue section from the epicenter and at $1 \mathrm{~mm}$ rostral and caudal to it were labeled with the monoclonal antibody CC1 (APC-7; Oncogene Research Products, Cambridge, MA), a polyclonal antibody to glial 
fibrillary acid protein (GFAP; Zymed Laboratories Inc., San Francisco, CA), or the monoclonal antibody OX-42 (Serotec; Harlan, Westbury, NY). Adjacent slides from each level of the cord were stained with hematoxylin. CC1 (APC-7) is an antibody to the adenomatous polyposis coli (APC) tumor suppressor gene that has been shown to label oligodendrocytes (Bhat et al., 1996; Crowe et al., 1997; Shuman et al., 1997). In each rat, immunolabeling was examined in two or three sections at each level of the cord (epicenter $\pm 1 \mathrm{~mm}$ rostral and caudal of the lesion) with a minimum distance of $50 \mu \mathrm{m}$ separating the sections examined.

Primary antibodies were used at a dilution of 1:1000 for CC1 and OX-42 and 1:100 for GFAP. Endogenous peroxidase was quenched with $0.3 \%$ hydrogen peroxide for $20 \mathrm{~min}$, and the tissue was washed with 0.1 M Tris buffer, $\mathrm{pH} 7.4$, and blocked for $1 \mathrm{hr}$ with $3 \%$ serum. Sections were exposed to the primary antibody overnight at $4^{\circ} \mathrm{C}$. The next day, tissue was exposed to the secondary antibody for 30-45 min, and labeling was visualized using the $\mathrm{ABC}$ peroxidase technique (Vector Laboratories, Burlingame, CA) with 3,3'-diaminobenzidine with and without $1 \%$ nickel chloride or the VIP substrate kit (Vector Laboratories) as the chromagen. Labeled cell counts were performed within the same region described for glial counts (Fig. $1 A$ ). Only cells with a clearly defined round nucleus and that were intensely immunolabeled were counted.

Statistical analysis. The experimental treatments, NBQX and VEH, were compared with uninjured controls using a one-factor ANOVA test and post hoc comparison with a Dunnett test. Comparison between NBQX and VEH, at 4 or $24 \mathrm{hr}$ after injury, was made using Student's $t$ test. Statistical comparison was performed using the Sigmastat program (SPSS). We did not statistically compare 4 and $24 \mathrm{hr}$ data because the experimental design was chosen to look at treatment differences at $4 \mathrm{hr}$ in the first study and at $24 \mathrm{hr}$ in the second. A comparison of the uninjured controls from the two studies was conducted with a Student's $t$ test, and the two groups were found to be similar $(p=0.823)$; therefore, the data were pooled. In all cases, statistical significance was established with $p<0.05$.

\section{RESULTS}

\section{Hindlimb function}

All injured animals killed at $24 \mathrm{hr}$ after injury had CBS scores of $\geq 95$ and $\mathrm{BBB}$ scores of 0 , demonstrating profound hindlimb deficits. All uninjured control animals had CBS scores of 0 and $\mathrm{BBB}$ scores of 21 , consistent with normal hindlimb function.

\section{Assessment of acute WM pathology}

In normal tissue, axons in the ventromedial area appeared as round or slightly oval structures that could be categorized as small, medium, and large based on their various diameters (Fig. $1 B)$. A darkly stained rim of compact myelin, proportional to the axon diameter, surrounded each axon. Axons were tightly packed with glia dispersed in between (Fig. $1 B$, inset) but with otherwise very little extra-axonal space. The extra-axonal space consisted primarily of a confluent matrix composed mainly of astrocytic processes. Also visible in the ventral WM were axons projecting from motoneurons located in the ventral horns (Fig. 1A,B). EM showed the intramyelinic area of normal axons to be completely filled with axoplasm (Fig. 1C). Even distribution of neurofilaments and microtubules gave the axoplasm a granular appearance. Throughout the axoplasm were numerous mitochondria.

The most notable change in the appearance of the tissue, after injury, was the formation of swollen axonal profiles and the decrease in healthy-looking, large-diameter axons by $4 \mathrm{hr}$ after SCI (Fig. 2A). Many axons appeared to have lost their round and oval shapes (Fig. 2C). The axoplasm, which in normal tissue appeared light in color, was dark in appearance in the $\mathrm{VEH}$ tissue. Lucent spaces were present throughout the extra-axonal matrix (Fig. 2C). EM showed injured axons demonstrating a number of pathologies such as axoplasmic condensation, the formation of vesicles and vacuoles, and periaxonal spaces (Fig. $2 E)$. Neurofilaments were compacted, giving the axoplasm a condensed appearance. There were notably fewer microtubules.
Axons demonstrating axoplasmic condensation often exhibited periaxonal spaces.

Disruption of the myelin was more evident with EM than LM. EM showed the myelin sheaths to be extensively unraveled and in some instances appeared as whorls of thread-like membranous matter. The large-diameter $(\geq 5 \mu \mathrm{m})$ axons appeared the most affected by injury, whereas the smaller axons $(\leq 2.5 \mu \mathrm{m})$ were only slightly altered.

Treatment with NBQX dramatically reduced the appearance of pathology at the LM level. At $4 \mathrm{hr}$ after injury, ventromedial tissue in the NBQX-treated group looked very similar to normal (Fig. 2B). Axons retained their round or oval shapes. Normalappearing large-diameter axons not seen in the VEH group were present in the NBQX group. There was a slight increase in extra-axonal spacing in the NBQX-treated group, but overall, generally there was good preservation of the glia matrix (Fig. $2 D$ ). EM revealed many of the axons in the NBQX group to contain axoplasm having structurally intact neurofilaments and microtubules. Although a number of axons with unraveled myelin in NBQX-treated tissue were seen, there were also quite a few with normal-looking myelin (Fig. $2 F$ ).

By $24 \mathrm{hr}$ after injury, large myelin profiles devoid of axoplasm were present throughout the VEH tissue (Fig. $3 A$ ). Holes within the extra-axonal matrix, thought to be indicative of lost axons and glia, were also present. Pathology in the remaining axons at $24 \mathrm{hr}$ resembled that observed at $4 \mathrm{hr}$ after injury (Figs. $2 C, 3 C$ ). EM confirmed that although the progression of the pathology appeared to have stabilized by $24 \mathrm{hr}$ after injury regardless of treatment, more of the axons in the $\mathrm{VEH}$ group continued to demonstrate varying degrees of pathology (Fig. 3E). Only smaller-diameter axons retained their normal appearance in the $\mathrm{VEH}$ group. In the NBQX-treated tissue there were normalappearing axons of all sizes.

The pathology in the NBQX group at $24 \mathrm{hr}$ after SCI looked remarkably like that observed in the $\mathrm{VEH}$ group at $4 \mathrm{hr}$ after injury. However, there tended to be greater numbers of normallooking axons and glia per area tissue in the NBQX group compared with VEH (Fig. 3B,D). Noteworthy was the presence of axonal mitochondria, which appeared more prevalent in NBQXtreated axons. Most striking was the change in myelin pathology. By 24 hr, myelin pathology appeared reduced in both $\mathrm{VEH}$ and NBQX groups. However, in the NBQX group, many of the remaining axons tended to be surrounded by intact, tightly compacted myelin sheaths, whereas axons in the VEH group often demonstrated thin myelin or abnormal spacing between the myelin lamellae.

\section{Quantification of WM pathology}

The diameter and pathological state of each axon present in the EM micrograph were assessed. Axons, based on their diameters, were categorized as small $(\leq 2 \mu \mathrm{m})$, medium $(3-4 \mu \mathrm{m})$, or large $(\geq 5 \mu \mathrm{m})$. Table 2 shows the average total axons per experimental group as well as the averages for each size category. By 4 hr after injury, the overall number of axons had been reduced by $\sim 34 \%$ mostly because of the loss of medium- and large-diameter axons. Treatment with NBQX significantly reduced this early loss, but by $24 \mathrm{hr}$ after injury, the total numbers of axons in NBQX and VEH groups were similar.

Assessment of axonal pathology with the AII showed a significant reduction of overall pathology (axoplasmic, myelinic, and periaxonal spacing) at both 4 and $24 \mathrm{hr}$ after SCI with NBQX treatment (Fig. 4). Examination of the individual components of 

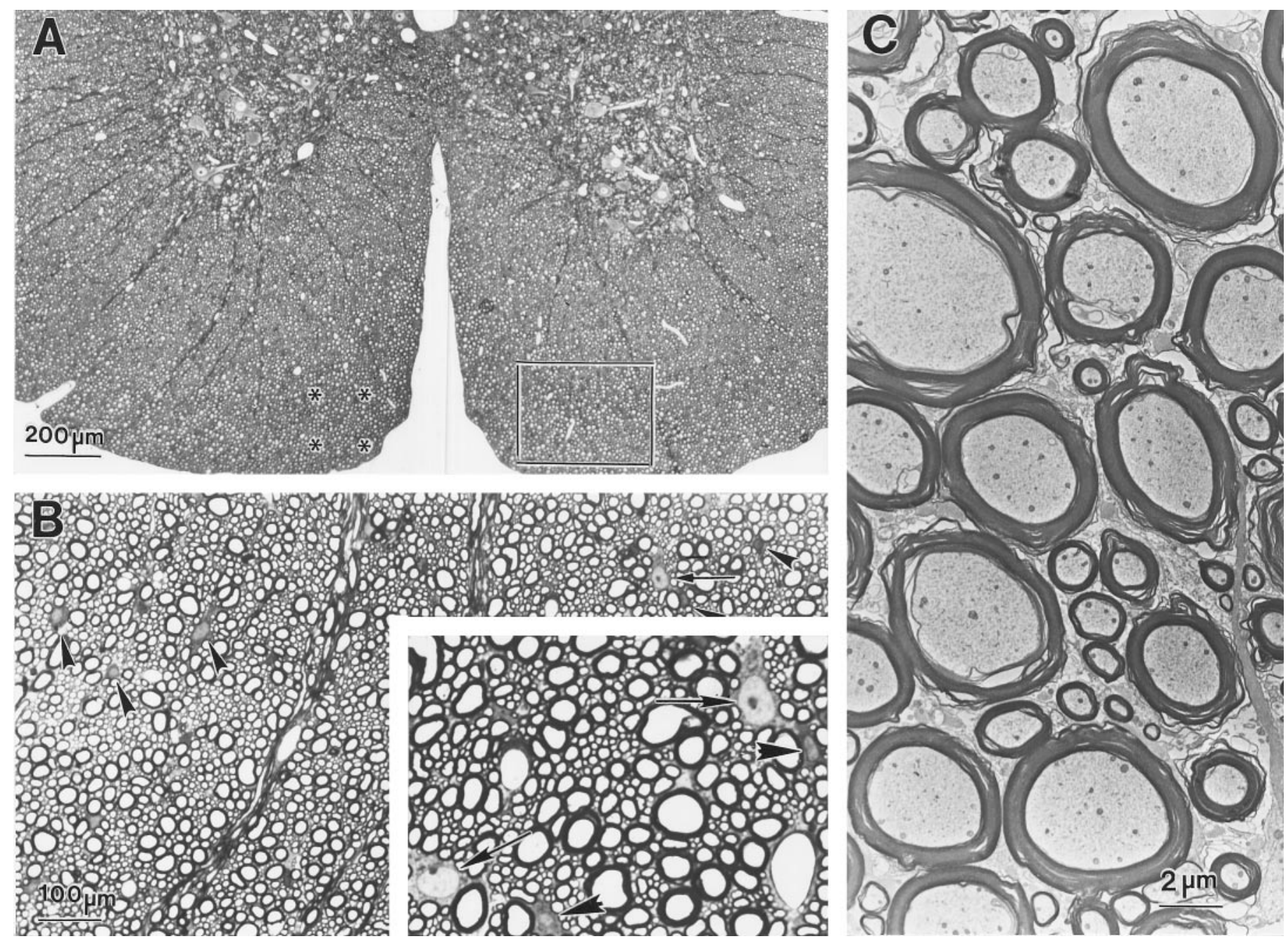

Figure 1. Uninjured ventral spinal cord tissue in the adult rat. $A$, The asterisks denote the four areas sampled in ventromedial WM to calculate the axonal injury index. The box indicates the tissue area used for glial counts. $B$, Higher magnification of ventromedial WM showing glial cell bodies interspersed among the myelinated axons. Both small, dark (arrowheads) and larger, pale (arrows) glia are visible. With higher magnification (inset), intact nuclear envelopes and nucleoli can be seen, and the differences between glial types are more evident. The large pale cells are identified as astrocytes (arrows), and the smaller dark cells are identified as oligodendrocytes (arrowheads) (Peters et al., 1991). C, An electron micrograph shows the variety of axonal sizes present in ventromedial WM. The normal spatial organization of the neurofilaments and microtubules and distribution of mitochondria can be seen within the axoplasm.

the AII found axoplasmic pathology was only slightly decreased with NBQX at $4 \mathrm{hr}$ after injury but significantly reduced with treatment by $24 \mathrm{hr}$ after injury (Fig. $5 A$ ). The results were much the same for myelin pathology in that both the NBQX and $\mathrm{VEH}$ groups demonstrated similar disturbances at $4 \mathrm{hr}$ after injury, yet by $24 \mathrm{hr}$ after SCI, myelin pathology had been greatly reduced in the NBQX-treated group (Fig. 5B). With NBQX treatment, myelin pathology was reduced by $50 \%$ compared with the $\mathrm{VEH}$ group. Periaxonal spacing, the third pathology category of the AII, was unaffected by NBQX treatment (data not shown).

\section{Quantification of glia}

Glial cells in the ventromedial region tended to be either large with prominent euchromatic nuclei and an extensive cytoplasm or small with heterochromatic nuclei and a more condensed cytoplasm that agree with descriptions of astrocytes and oligodendrocytes, respectively (Peters et al., 1991). In normal tissue stained with $1 \%$ toluidine, the larger glia generally stained light blue, whereas the smaller cells tended to stain dark blue (Fig. 1B, inset).
Injury, unfortunately, altered the glia, making identification based solely on their appearance difficult. Therefore, glia counts included all cells that demonstrated a round, intact nucleus.

By $4 \mathrm{hr}$ after injury, there was a reduction in glial numbers in the VEH group to $39 \%$ of those in uninjured controls (Fig. 6). With NBQX treatment, there was less of a decrease; $68 \%$ of the normal number of glial nuclei were preserved. No significant additional loss of glia was seen at $24 \mathrm{hr}$ after injury in either the $\mathrm{VEH}$ (35\% of the normal number) or NBQX (77\% of normal) groups (Fig. 6).

\section{Immunohistochemical determination of specific glia populations}

CC1-, GFAP-, and OX-42-labeled glia differed in cell shape, size, and response to injury. Cell location within the tissue also differed depending on subtype. CC1-positive cells were evenly distributed throughout the ventral WM. In normal tissue, CC1positive cells had an oval or irregular-shaped cell body with fine, thin processes radiating from the body (Fig. $7 A, B$ ). With injury, 

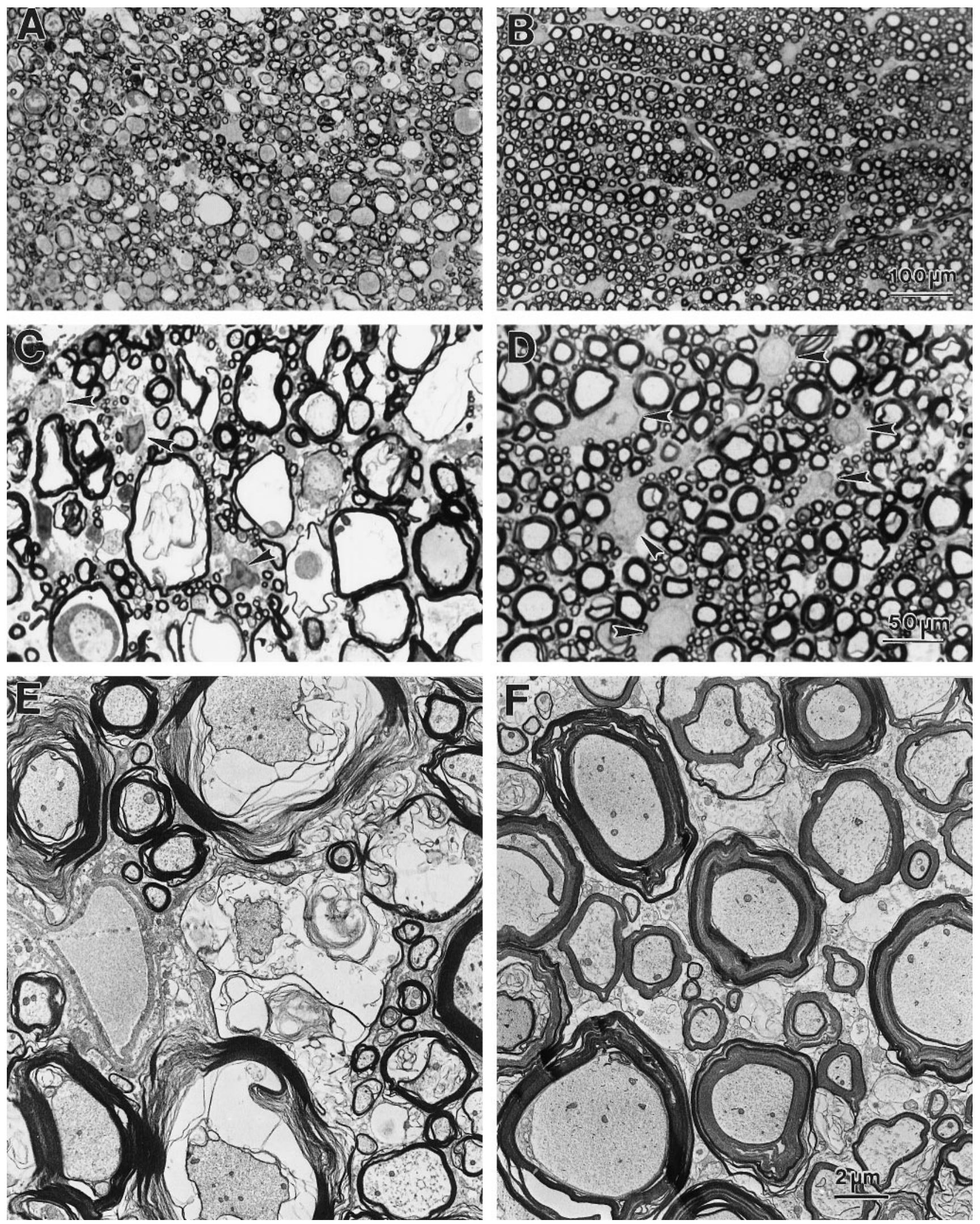

Figure 2. Pathology in ventromedial WM of $\operatorname{VEH}(A, C, E)$ and NBQX-treated $(B, D, F)$ tissue at 4 hr after SCI. $A$, Numerous swollen axon profiles characterize the VEH control tissue. Many axons demonstrate abnormal myelination. $B$, In the NBQX-treated tissue only a slight increase in extra-axonal spacing indicates the presence of injury. $C$, At higher magnification, axonal pathology in the VEH tissue is seen primarily in the mediumand large-diameter axons. Glia appear darkened and shriveled (arrowheads). D, In the NBQX-treated tissue, glia are more numerous (arrowheads) and appear relatively normal. $E$, Electron microscopy reveals periaxonal spaces and severe myelin unraveling present in VEH control tissue. $F$, In contrast, NBQX-treated tissue shows less pathology in the axoplasm and myelin sheaths. 

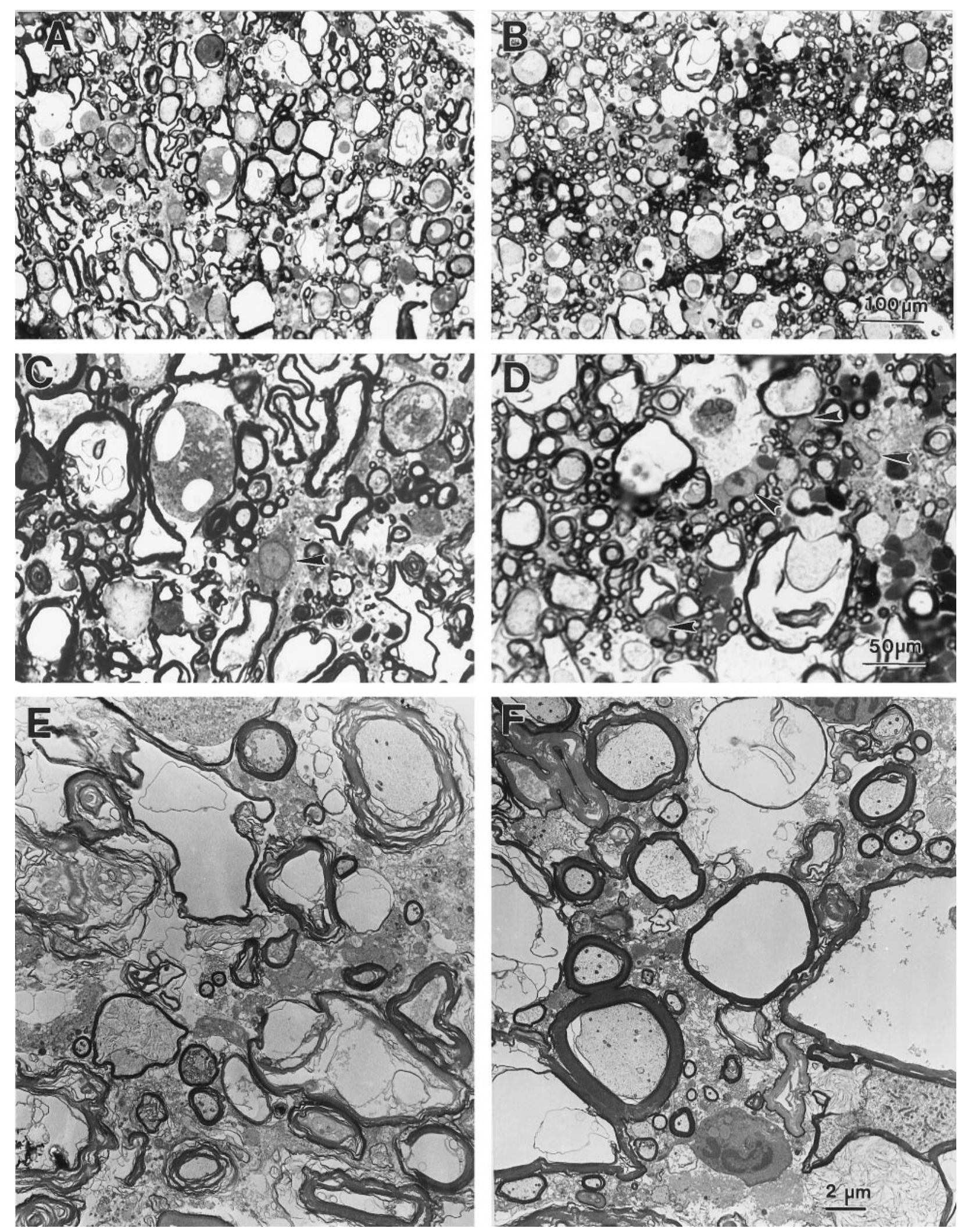

Figure 3. Pathology in VEH $(A, C, E)$ and NBQX-treated $(B, D, F)$ tissue at $24 \mathrm{hr}$ after SCI. $A$, Large, swollen axonal profiles are present in VEH tissue. Increased extra-axonal spacing is also seen and considered indicative of axon and glial loss. $B$, Fewer large axonal profiles and less extra-axonal space are apparent in NBQX-treated tissue. $(C)$ At higher magnification, some small axons can be seen with relatively normal morphology in VEH tissue. A single glial cell body is seen in the field (arrowhead). D, In NBQX-treated tissue, more normal-appearing small axons and glia cell bodies (arrowheads) are evident. E, Electron microscopy of VEH-treated tissue demonstrates empty myelin cysts and extensive axoplasmic and myelin pathology of remaining axons, with the exception of a few small-diameter axons that appear relatively normal. $F$, In NBQX-treated tissue more of the axons, including larger ones, retain axoplasmic organization and normal-appearing myelination. 
Table 2. Axon counts in ventromedial WM

\begin{tabular}{lllll} 
Axons & $\begin{array}{l}\text { Uninjured } \\
(n=9)\end{array}$ & $\begin{array}{l}\text { Vehicle } 4 \mathrm{hr} \text { PI } \\
(n=6)\end{array}$ & $\begin{array}{l}\text { NBQX 4 hr PI } \\
(n=5)\end{array}$ & $\begin{array}{l}\text { Vehicle 24 hr PI } \\
(n=5)\end{array}$ \\
\hline Total & $123 \pm 7$ & $81 \pm 13^{*}$ & $118 \pm 14^{* *}$ & $86 \pm 11^{*}$ \\
Small $(\leq 2 \mu \mathrm{m})$ & $64 \pm 4$ & $49 \pm 11$ & $78 \pm 10$ & $52 \pm 6$ \\
Medium $(3-4 \mu \mathrm{m})$ & $28 \pm 2$ & $18 \pm 2^{*}$ & $24 \pm 3$ & $17 \pm 2^{*}$ \\
Large $(\geq 5 \mu \mathrm{m})$ & $29 \pm 3$ & $14 \pm 1^{*}$ & $18 \pm 1^{* * * *}$ & $11 \pm 3^{*}$
\end{tabular}

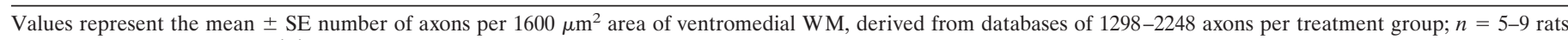
per treatment group. PI, Postinjury.

*Value is significantly different from uninjured controls (one-factor ANOVA with Dunnett post hoc comparison, $p<0.05$ ).

$* *$ Value is significantly different from vehicle (Student's $t$ test, $p<0.05$ ).

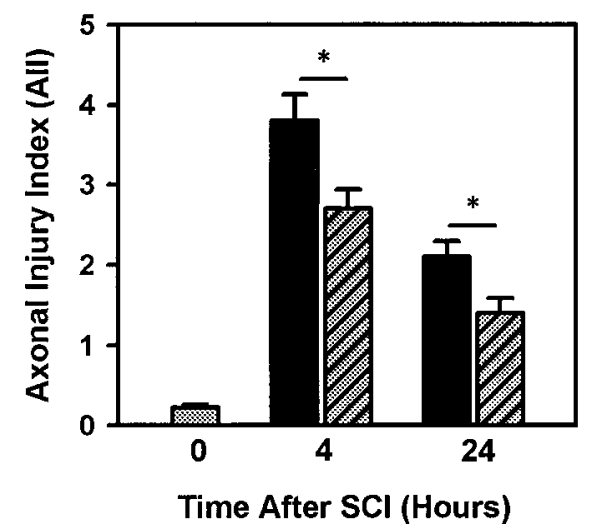

Figure 4. Assessment of overall pathology with the AII. Compared with

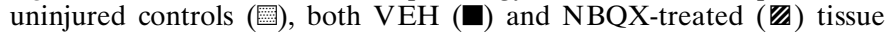
show significantly more pathology (Dunnett post hoc, $p<0.05$ ). NBQX treatment significantly reduces overall pathology $(*)$ compared with VEH at $4 \mathrm{hr}(t$ test, $p=0.035)$ and $24 \mathrm{hr}(t$ test, $p=0.024)$ after SCI. The bars represent the means \pm SEs for $n=5-6$ rats per experimental group and $n=9$ uninjured controls.

the cell body rounded and processes disappeared (Fig. 7C,D). In the NBQX-treated tissue, the cell bodies also became rounded, although not as much as in the $\mathrm{VEH}$ group, and the processes were retained, although they appeared shorter (Fig. 7E,F).

GFAP-positive cells in normal tissue tended to have large, irregularly shaped cell bodies and thick possesses, branching for considerable distances. GFAP-positive cells were mostly confined to the deep ventral WM or aligned with the axonal arrays extending from the ventral motoneurons (Fig. $8 A$ ). Injury increased labeling intensity, making the processes appear more prominent. The processes also appeared to be more abundant (Fig. 8B). Unlike the CC1-positive cells, GFAP-positive cells retained their basic morphological appearance after injury (Fig. 8C).

OX-42 labeled a small population of cells sparsely scattered throughout ventral WM. The cell bodies were slightly smaller than those labeled by $\mathrm{CC} 1$ or GFAP, and the processes were exceptionally thin and extensively branched in normal tissue (Fig. $8 D$ ). Injury caused the processes to thicken and shorten (Fig. $8 E$ ).

Hematoxylin staining of frozen sections showed there to be $70.2 \pm 6.5$ (mean \pm SE; $n=3$ rats) nuclei in an area of normal ventromedial tissue $500 \times 700 \mu \mathrm{m}$ and $20 \mu \mathrm{m}$ thick. Injury reduced this number to $44 \%$ of normal in the VEH group (31 \pm 2.8 nuclei), which was in agreement with the glial counts from the $1 \mu \mathrm{m}$ plastic sections (see preceding section). Approximately $71 \%$ of the normal number of glial nuclei were seen with NBQX treatment $(50 \pm 3.6)$, again similar to our findings in $1 \mu \mathrm{m}$ plastic sections.
In uninjured control tissue, CC1 labeling identified $43 \%$ of the glia in the ventromedial WM area analyzed as oligodendrocytes. In both the NBQX and VEH groups, the numbers of $\mathrm{CC} 1$ positive cells were significantly reduced (Fig. $9 A$ ). Less than half $(49 \%)$ of the normal number of oligodendrocytes were present at $24 \mathrm{hr}$ in the VEH group. However, compared with the VEH group, we found a significant sparing of CC1-positive glia with NBQX treatment $(14.6 \pm 0.8$ vs $20.8 \pm 2.3$, respectively); $\sim 71 \%$ of the normal number of oligodendrocytes were preserved.

GFAP labeled $\sim 30 \%$ of the glia in uninjured control tissue. Injury caused a significant reduction in the numbers of GFAPlabeled cell bodies, although we did observe intensified labeling of the remaining processes, and an apparent increase in the abundance of processes, which may reflect reactive gliosis brought about by the trauma (Fig. $8 B$ ). Comparison of VEH and NBQX groups found no significant differences with regard to cell counts $(11.3 \pm 1.3$ vs $13.9 \pm 1.0$, respectively), indicating there was no significant sparing of astrocytes with NBQX treatment.

Of the remaining nuclei, negative for both $\mathrm{CC} 1$ and GFAP, approximately half labeled positively for the microglial marker OX-42. Compared with uninjured controls (10.4 \pm 0.43$)$, microglial numbers were not altered in the ventromedial region by $24 \mathrm{hr}$ after injury in either the NBQX or VEH group $(8.3 \pm 1.2$ and $10.2 \pm 1.0$, respectively). Approximately $12 \%$ of the nuclei were not accounted for with the antibodies CC1, GFAP, and OX-42. Some of the nuclei appeared to be endothelial cells, as indicated by their flattened appearance. The other cells, unidentified with immunohistochemical markers, had physical features similar to glia and may reflect a small population of glia precursor cells present in adult ventromedial WM (Wrathall et al., 1998).

\section{DISCUSSION}

This study demonstrates that focal treatment with NBQX significantly reduces acute white matter pathology after SCI. By $4 \mathrm{hr}$ after injury, extensive axoplasmic and myelin pathology was seen in the ventromedial white matter of the vehicle group. By this time significant numbers of axons and glia had already been lost as a result of the injury. In the NBQX-treated group at $4 \mathrm{hr}$, there was less glial cell loss, overall axonal pathology was significantly decreased, and axonal numbers were not significantly reduced compared with uninjured controls. Most of these effects of NBQX treatment were still seen at $24 \mathrm{hr}$ after injury. Axon loss was detected in the NBQX-treated group, but the degree of axoplasmic and myelin pathology in the surviving axons was significantly lower than in vehicle controls. Significant preservation of glial cells was seen at 4 and $24 \mathrm{hr}$ after SCI with NBQX treatment. Furthermore, immunohistochemical evidence indicated that glial sparing by NBQX reflected a sparing of oligodendrocytes that were otherwise lost during the first $24 \mathrm{hr}$ after SCI. 
A

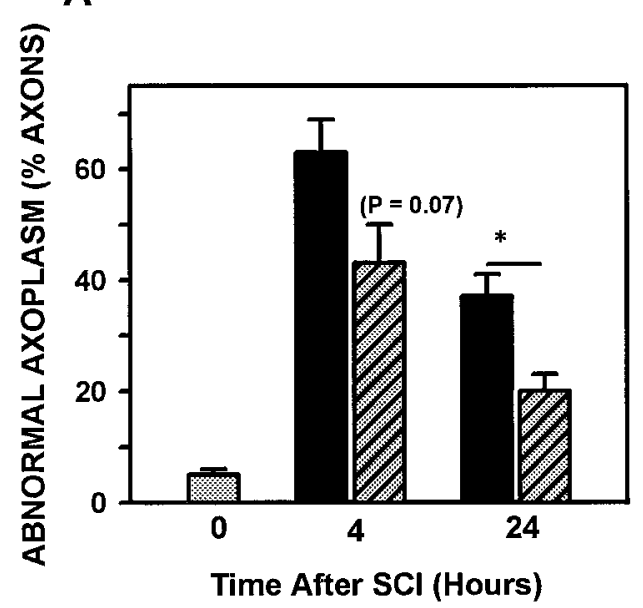

B

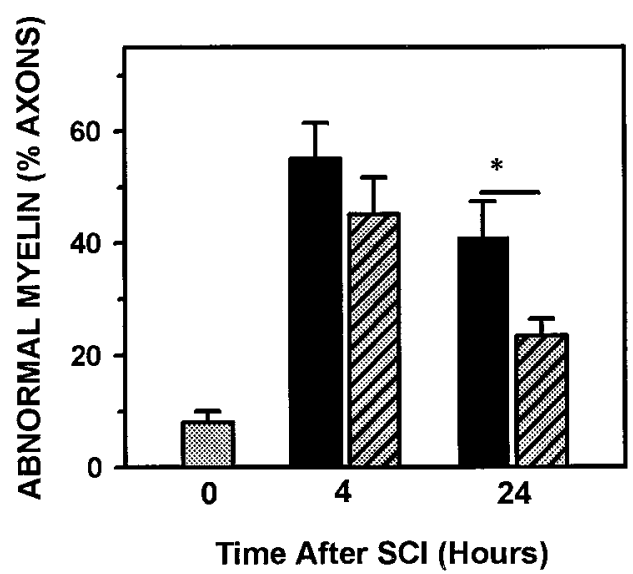

Figure 5. Quantitative assessment of axoplasmic $(A)$ and myelin $(B)$ pathology. Compared with uninjured controls (墙), axoplasmic pathology $(A)$ is significantly greater in both the VEH $(\square)$ and NBQX-treated ( $)$ groups at 4 and $24 \mathrm{hr}$ after SCI (Dunnett post hoc, $p<0.05$ ). At $24 \mathrm{hr}$ after injury, axoplasmic pathology is significantly reduced with NBQX compared with VEH treatment $(t$ test, $p=0.008)$. $B$, Myelin pathology is significantly increased at $4 \mathrm{hr}$ after SCI in both VEH and NBQX-treated groups (Dunnett post hoc, $p<0.05$ ). By $24 \mathrm{hr}$ after injury, significantly less myelin pathology was observed with NBQX treatment compared with VEH $(t$ test, $p=0.042)$. At 24 hr there is no significant difference between the NBQX group and uninjured controls (Dunnett post hoc, $p>0.05$ ). The bars represent the means \pm SE for $n=5-6$ experimental rats per group and $n=9$ uninjured controls.

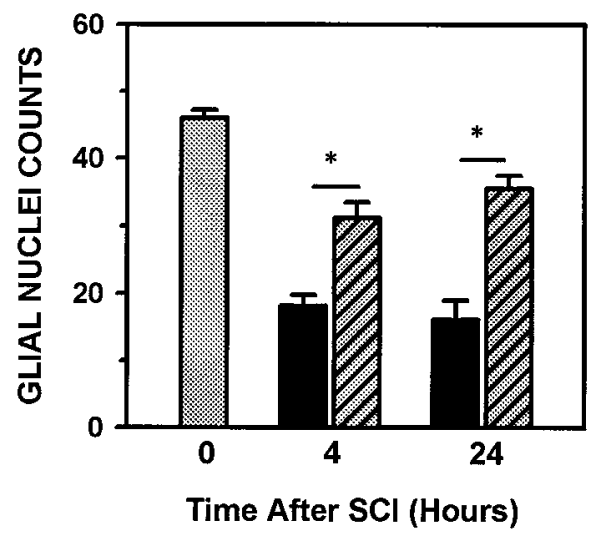

Figure 6. Effect of NBQX on numbers of glial nuclei in ventromedial WM. The numbers of glial cell nuclei in $1 \mu \mathrm{m}$ plastic sections of VEH (ם) tissue are significantly reduced compared with uninjured controls (畻) (Dunnett post hoc, $p<0.05$ ), whereas there is no significant reduction in the NBQX-treated group. A significant sparing is seen with NBQX treatment $(\mathbb{Z})$ compared with VEH at $4 \mathrm{hr}(t$ test, $p<0.001)$ and $24 \mathrm{hr}$ ( $t$ test, $p<0.001)$ after SCI. The bars represent the means \pm SE for $n=$ 5-6 experimental rats and $n=9$ uninjured controls.

These significant effects of NBQX on acute WM pathology were not accompanied by reduced hindlimb deficit at $24 \mathrm{hr}$ after injury. This is consistent with previous results with NBQX, which produced dramatic improvement in hindlimb function at 1, 2, 3, and 4 weeks after SCI but not at 24 hr (Wrathall et al., 1994). Typically rats are areflexic at $1 \mathrm{~d}$ after injury and still experiencing "spinal shock" (Atkinson and Atkinson, 1996); thus, beneficial effects on somatic sensory motor function below the level of the lesion are obscured.

Our results are also comparable with previous studies of acute pathology in white matter after spinal cord injury (Lampert, 1967; Dohrmann et al., 1972; Bresnahan et al., 1976; Balentine, 1978). In a time course study with this injury model, we previously reported significant axonal loss and axoplasmic and myelin pa- thology in ventromedial white matter by $4 \mathrm{hr}$ after injury (Rosenberg and Wrathall, 1997). A reduction in pathology was observed between 4 and $24 \mathrm{hr}$; thus, surviving axons demonstrated some recovery by $24 \mathrm{hr}$. NBQX treatment can enhance this recovery, because the difference between the $\mathrm{VEH}$ and NBQX-treated groups was greater at $24 \mathrm{hr}$ than at $4 \mathrm{hr}$. In our earlier study (Rosenberg and Wrathall, 1997), we found a correlation between degree of acute axonal pathology and injury severity, which is highly correlated to amount of chronic white matter loss. Similarly, in the current study the reduced acute white matter pathology appears correlated to the sparing of white matter seen at 1 month after NBQX treatment (Wrathall et al., 1994).

What is/are the mechanism(s) through which NBQX acts to produce white matter sparing? There are several possibilities. AMPA/kainate antagonists are known to reduce the effects of excitotoxicity on neurons in culture (Koh et al., 1990) and to reduce gray matter loss after spinal cord injury (Wrathall et al., 1994, 1997). Sparing of gray matter could lessen the release of toxic substances that might exacerbate pathology in surrounding white matter. Two observations argue against this hypothesis. The first is that in a previous study in which NBQX was given at $4 \mathrm{hr}$ after injury (Wrathall et al., 1997), significant chronic gray matter sparing was observed in the absence of white matter sparing. Second, in the current study, a significant reduction in white matter pathology with NBQX treatment was evident by $4 \mathrm{hr}$ after injury. It appeared likely that NBQX acted before this time point to enhance survival of glial cells, because a significant difference in numbers was already apparent by $4 \mathrm{hr}$ after SCI. Both of these observations suggest that a direct action of NBQX in white matter is more likely than an indirect action through sparing of gray matter. The hypothesis that NBQX acts directly on white matter leads to the prediction that focal injections directly into white matter "at risk" after SCI should produce an equivalent or even greater effect on acute axonal pathology than injection into the lesion epicenter. However, further studies are needed to test the hypothesis in vivo. A direct action of NBQX on 

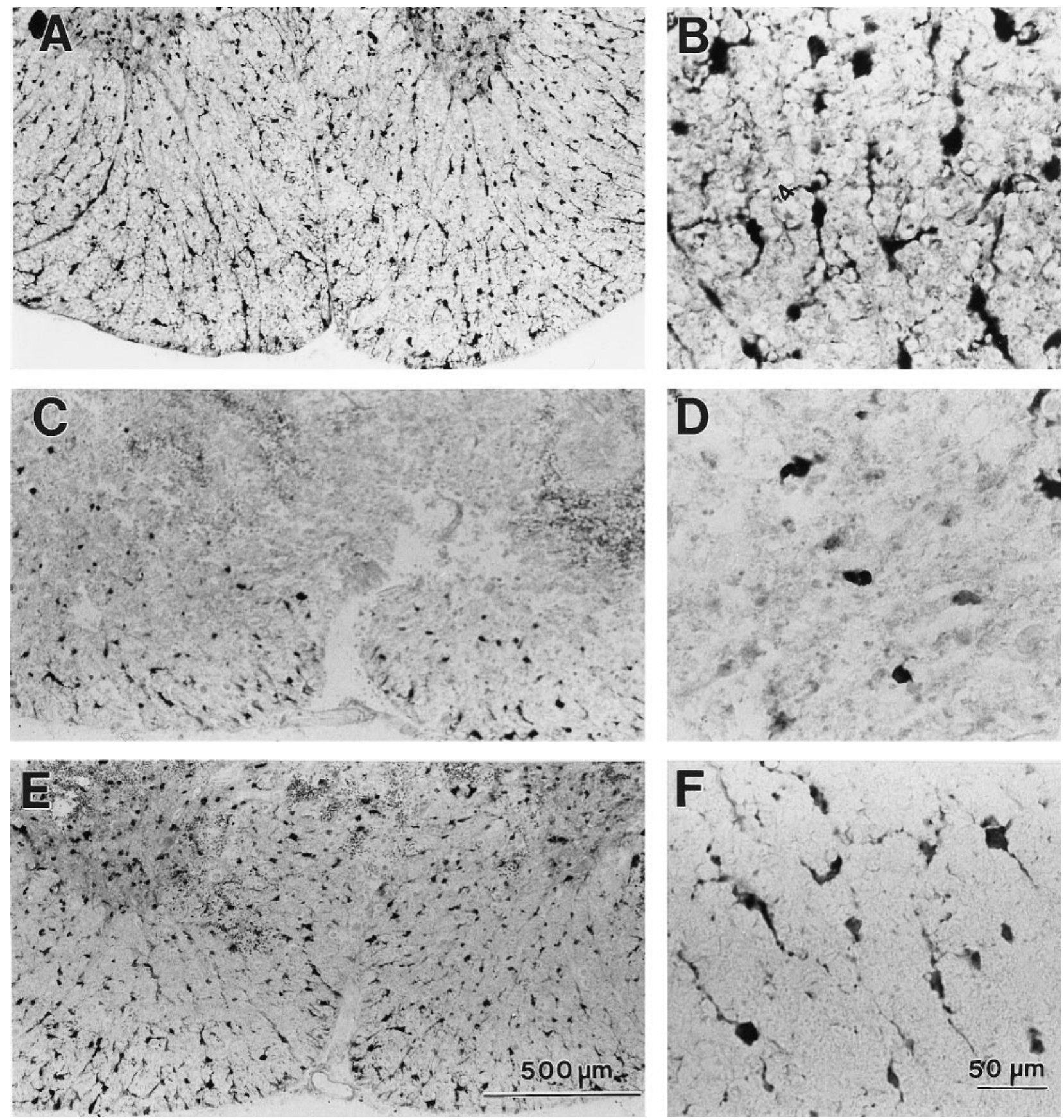

Figure 7. CC1-immunoreactive oligodendrocytes in ventromedial WM in uninjured tissue $(A, B)$ and 24 hr after SCI and treatment with VEH $(C, D)$ or NBQX $(E, F) . A$, Normal labeling is seen in glia distributed throughout ventromedial WM. $B$, With higher magnification, the labeling is seen in rounded cell bodies and their multiple branched processes. $C$, The number of labeled cells is visibly decreased in the VEH group. $D$, The cell bodies appear more rounded, and processes are no longer visible after injury. $E$, In the NBQX group, numerous CC1-labeled cells are seen at 24 hr after SCI. $F$, The cells retain labeled processes, although branching appears reduced compared with uninjured controls $(B)$.

WM has been shown in an in vitro preparation of white matter subjected to compression injury (Agrawal and Fehlings, 1997).

Could NBQX act directly on axons in the ventromedial white matter? This would be possible if AMPA/kainate receptors were present. However, there is no evidence of functional glutamate receptors on axons except for presynaptic receptors at axon terminals. Although immunohistochemical evidence for the presence of the GluR1 subunit of the AMPA receptor has been reported in myelinated axons within the hippocampus (Martin et al., 1993), and evidence of both NMDA and non-NMDA recep- tor subunits has been found in peripheral nerves, it is more likely that the observed immunoreactivity is associated with receptor complexes being transported from the cell body to axon terminals (Coggeshall and Carlton, 1998).

Another possibility is that the protection conveyed by NBQX is mediated by glia located in the white matter. Functional AMPA/ kainate receptors are known to be present on glia (Gallo and Russell, 1995; Bernstein et al., 1996; Chen et al., 1997). The AMPA subunits GluR1-4 have been detected in glia in vivo using reverse transcription-PCR analysis in combination with immuno- 

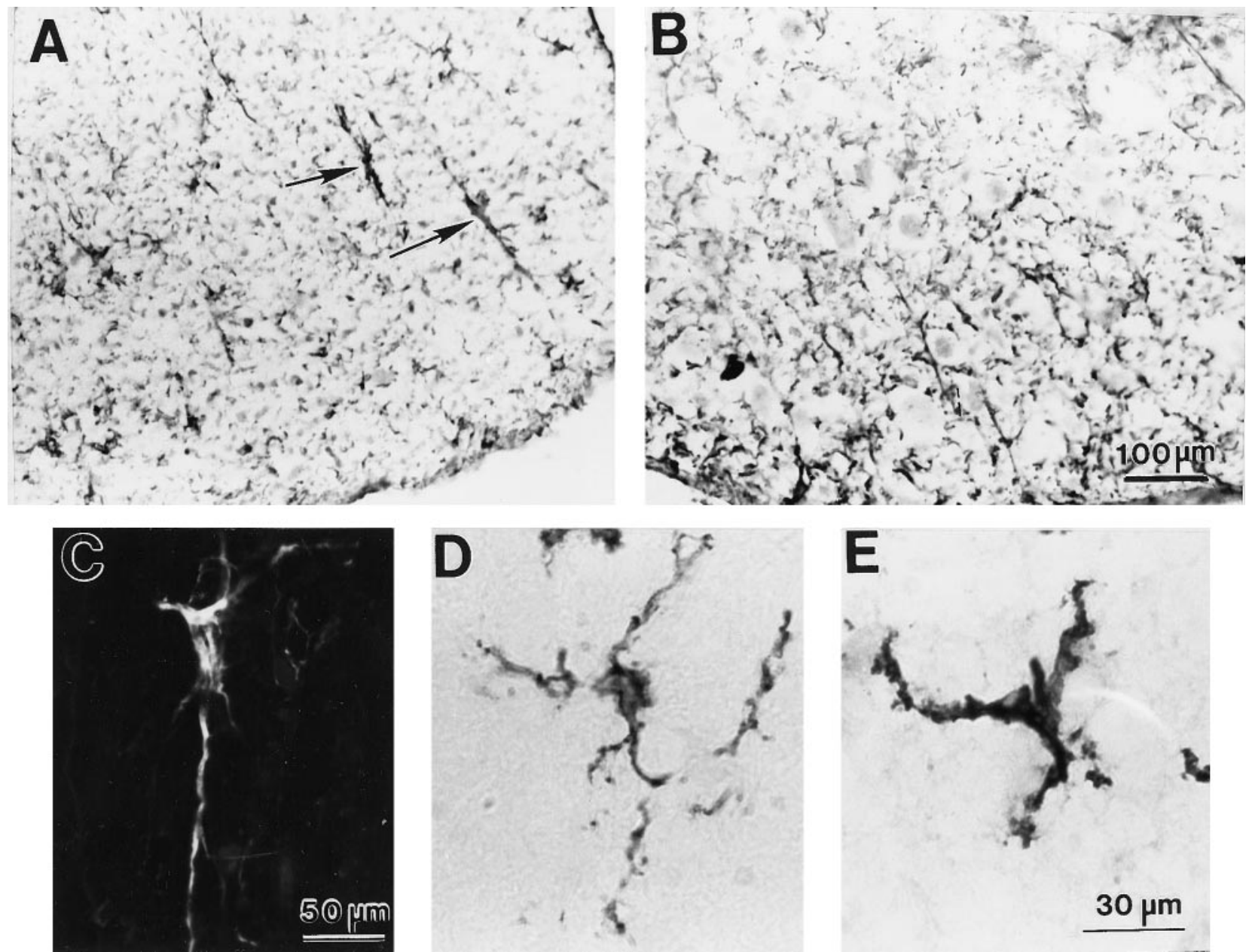

Figure 8. GFAP- and OX-42-labeled glia in ventromedial WM. $A$, GFAP labeling of astrocytes in normal ventromedial WM. Arrows indicate cell bodies of GFAP-positive astrocytes. $B$, At $24 \mathrm{hr}$ after SCI in the VEH group, there is an apparent reduction in the number of GFAP-positive cell bodies, although immunreactive cell processes are even more evident than in uninjured tissue. $C$, At higher magnification, a GFAP-labeled astrocyte in VEH-treated ventromedial WM is seen to be larger than CC1-positive oligodendrocytes (Fig. 7B) and exhibits longer processes and a less-rounded cell body. $D$, OX 42-positive microglia in uninjured WM were smaller than the CC1- and GFAP-positive cells and have multiple thin processes. E, At 24 hr after SCI, OX 42 labeling intensity was increased, and microglia showed a thickening of their processes.

histochemistry (Garcia-Barcina and Matute, 1998). Doublelabeling experiments using antibodies against the AMPA subunits and glial cell markers in adult bovine white matter showed that receptor subunits GluR1-3 were localized primarily in astrocytes. The GluR4 subunit was seen in oligodendrocytes. There are some discrepancies with regard to findings in vivo and in vitro; however, the data clearly support the presence of AMPA and kainate receptor subunits in oligodendrocytes and astrocytes (Agrawal and Fehlings, 1997; Matute et al., 1997; McDonald et al., 1998).

Interestingly, NMDA receptors appear to be absent in white matter (Matute and Miledi, 1993; Tachibana et al., 1994; Matute et al., 1997). This may explain why NMDA antagonists appear less effective than the AMPA/kainate antagonist NBQX after thoracic spinal cord injury (Wrathall et al., 1992b, 1994) (J. R. Wrathall, unpublished results) in which most of the functional deficits measured, i.e., hindlimb function, are attributable to white matter loss. Similarly, blockade of AMPA/kainate receptors was found to be more effective than blockade of NMDA receptors in restoring compound action potentials in an in vitro model of white matter compression injury (Agrawal and Fehlings, 1997). The simplest hypothesis to account for these results is that
NBQX is acting through AMPA/kainate receptors on glial cells in the white matter (Wrathall et al., 1994; Agrawal and Fehlings, 1997).

Astrocytes play important roles in maintaining ionic homeostasis of the extracellular environment (Amedee et al., 1997). Loss of their function would have detrimental effects on surrounding axons (Sykova et al., 1992). However, astrocytes are fairly resistant to excitotoxicity (Oka et al., 1993; McDonald et al., 1998). Agrawal and Fehlings (1997), conducting studies of AMPA/ kainate receptor blockade and spinal WM compression injury in vitro, concluded that the recovery of compound action potentials seen after treatment was attributable to an NBQX-mediated enhancement of astrocyte function after injury. However, they did not investigate or address the role of oligodendrocytes in their model.

SCI significantly increases extracellular levels of excitatory amino acids (Panter et al., 1990; Liu et al., 1991). Oligodendrocytes are highly vulnerable to excitotoxic stresses (Matute et al., 1997; McDonald et al., 1998). Therefore, oligodendrocytes are likely targets of excitotoxicity. McDonald and colleagues (1998) found that microinjection of $20 \mathrm{nmol}$ of AMPA into the external capsule in adult rat brain was sufficient to kill $60 \%$ of the resident 

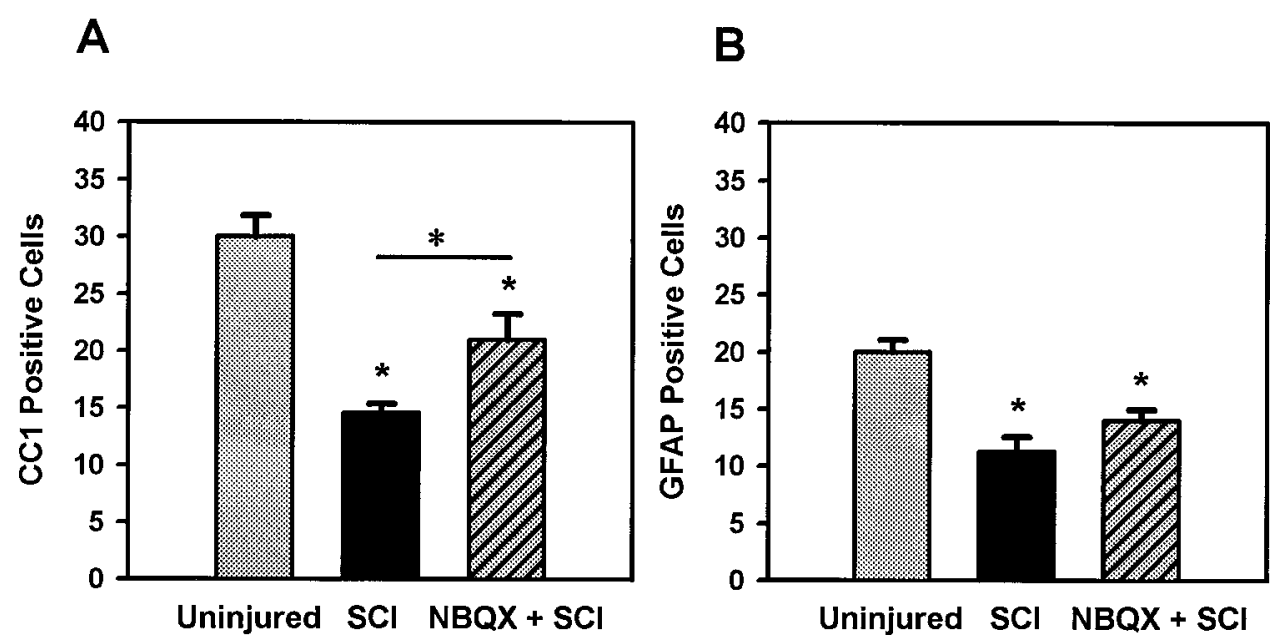

Figure 9. Effect of NBQX on survival of glial cells at $24 \mathrm{hr}$ after SCI. $A$, Compared with uninjured controls, numbers of CC1-positive oligodendrocytes in VEH and NBQX-treated groups were significantly reduced (Dunnett post hoc, $p<0.05$ ). Significantly more CC1-positive cells were observed with NBQX treatment compared with VEH $(t$ test, $p=0.029)$. $B$, GFAP-labeled astrocytes in both VEH and NBQX-treated tissue were significantly reduced after SCI compared with uninjured controls (Dunnett post hoc, $p<0.05$ ). No difference in number of GFAP-labeled cells was seen between VEH and NBQX groups ( $t$ test, $p=0.157)$. Bars represent means \pm SE for $n=6$ rats in each group.

oligodendrocytes. Our finding of significant sparing of oligodendrocytes at $24 \mathrm{hr}$ after SCI in the NBQX-treated group is consistent with reducing glutamate-mediated loss of these glia after injury.

The benefits seen with NBQX treatment in reducing acute white matter pathology are likely attributable, in part, to the sparing of oligodendrocytes. This would be expected to attenuate injury-mediated axonal demyelination, thereby preserving the functional integrity of the surviving axons. Our finding of significantly less myelin pathology in the NBQX-treated group at $24 \mathrm{hr}$, as well as enhanced myelination of residual WM at 1 month (Wrathall et al., 1994) (J. R. Wrathall, unpublished results), is consistent with this hypothesis. It seems likely that the acute treatment with NBQX not only reduces oligodendrocyte loss acutely but also preserves them from later apoptotic death observed for several weeks after SCI (Crowe et al., 1997; Shuman et al., 1997). A direct test of this hypothesis will require analysis of oligodendrocyte numbers and myelination at chronic time points after NBQX treatment.

The reduction in acute axoplasmic pathology by NBQX may involve an additional effect of NBQX on astrocytes. Although treatment did not reduce the loss of astrocytes at $24 \mathrm{hr}$ after injury, we speculate that blockade of astrocytic AMPA/kainate receptors by $\mathrm{NBQX}$ may beneficially alter astrocytic function after SCI as suggested by previous investigators (Agrawal and Fehlings, 1997), perhaps through a more rapid reestablishment of interaxonal ionic homeostasis. Clearly, the roles of glia and axonal-glia interactions after SCI are important (Barres, 1991; Barres and Raff, 1993; McTigue et al., 1998; Ramon-Cueto et al., 1998), and it is hoped that further study in this area will provide useful information about injury and repair mechanisms in the spinal cord after injury.

In summary, we have shown that focal injection of NBQX into the injury site after experimental spinal cord contusion significantly reduces pathology in ventromedial WM at 4 and $24 \mathrm{hr}$ after injury. The reduction of WM pathology with NBQX appears attributable, in part, to a significant sparing of oligodendrocytes normally lost after SCI. These findings increase our understanding of how AMPA/kainate receptors may be involved in second- ary injury to $\mathrm{WM}$ and add further support for the potential therapeutic use of their antagonists in traumatic SCI.

\section{REFERENCES}

Agrawal SK, Fehlings MG (1997) Role of NMDA and non-NMDA ionotropic glutamate receptors in traumatic spinal cord axonal injury. J Neurosci 17:1055-1063.

Amedee T, Robert A, Coles JA (1997) Potassium homeostasis and glial energy metabolism. Glia 21:46-55.

Atkinson PP, Atkinson JL (1996) Spinal shock. Mayo Clin Proc 71:384-389.

Balentine JD (1978) Pathology of experimental spinal cord trauma. II. Ultrastructure of axons and myelin. Lab Invest 39:254-266.

Barres BA (1991) New roles for glia. J Neurosci 11:3685-3694.

Barres BA, Raff MC (1993) Proliferation of oligodendrocyte precursor cells depends on electrical activity in axons. Nature 361:258-260.

Basso DM, Beattie MS, Bresnahan JC (1995) A sensitive and reliable locomotor rating scale for open field testing in rats. J Neurotrauma 12:1-21.

Bernstein M, Lyons SA, Moller T, Kettenmann H (1996) Receptormediated calcium signalling in glial cells from mouse corpus callosum slices. J Neurosci Res 46:152-163.

Bettler B, Mulle C (1995) Review: Neurotransmitter receptors II. AMPA and kainate receptors. Neuropharmacology 34:123-139.

Bhat RV, Axt KJ, Fosnaugh JS, Smith KJ, Johnson KA, Hill DE, Kinzler KW, Baraban JM (1996) Expression of the APC tumor suppressor protein in oligodendroglia. Glia 17:169-174.

Bracken MB, Shepard MJ, Collins WF, Holford TR, Young W, Baskin DS, Eisenberg HM, Flamm E, Leo-Summers L, Maroon J (1990) A randomized, controlled trial of methylprednisolone or naloxone in the treatment of acute spinal-cord injury. Results of the Second National Acute Spinal Cord Injury Study [see comments]. N Engl J Med 322:1405-1411.

Bresnahan JC, King JS, Martin GF, Yashon D (1976) A neuroanatomical analysis of spinal cord injury in the rhesus monkey (Macaca mulatta). J Neurol Sci 28:521-542.

Chen J, Backus KH, Deitmer JW (1997) Intracellular calcium transients and potassium current oscillations evoked by glutamate in cultured rat astrocytes. J Neurosci 17:7278-7287.

Choi DW, Rothman SM (1990) The role of glutamate neurotoxicity in hypoxic-ischemic neuronal death. Annu Rev Neurosci 13:171-182.

Choi DW, Maulucci-Gedde M, Kriegstein AR (1987) Glutamate neurotoxicity in cortical cell culture. J Neurosci 7:357-368.

Coggeshall RE, Carlton SM (1998) Ultrastructural analysis of NMDA, AMPA, and kainate receptors on unmyelinated and myelinated axons in the periphery. J Comp Neurol 391:78-86. 
Crowe MJ, Bresnahan JC, Shuman SL, Masters JN, Beattie MS (1997) Apoptosis and delayed degeneration after spinal cord injury in rats and monkeys. Nat Med [Erratum (1997) 3:240] 3:73-76.

Dohrmann GJ, Wagner Jr FC, Bucy PC (1972) Transitory traumatic paraplegia: electron microscopy of early alterations in myelinated nerve fibers. J Neurosurg 36:407-415.

Faden AI, Lemke IM, Simon RP, Noble LJ (1988) N-Methyl-Daspartate antagonist MK801 improves outcome following traumatic spinal cord injury in rats: behavioral, anatomic, and neurochemical studies. J Neurotrauma 5:33-45.

Gale K, Kerasidis H, Wrathall JR (1985) Spinal cord contusion in the rat: behavioral analysis of functional neurologic impairment. Exp Neurol 88:123-134.

Gallo V, Russell JT (1995) Excitatory amino acid receptors in glia: different subtypes for distinct functions? J Neurosci Res 42:1-8.

Garcia-Barcina JM, Matute C (1998) AMPA-selective glutamate receptor subunits in glial cells of the adult bovine white matter. Brain Res Mol Brain Res 53:270-276.

Gomez-Pinilla F, Tram H, Cotman CW, Nieto-Sampedro M (1989) Neuroprotective effect of MK-801 and U-50488H after contusive spinal cord injury. Exp Neurol 104:118-124.

Kerasidis H, Wrathall JR, Gale K (1987) Behavioral assessment of functional deficit in rats with contusive spinal cord injury. J Neurosci Methods 20:167-179.

Koh JY, Goldberg MP, Hartley DM, Choi DW (1990) Non-NMDA receptor-mediated neurotoxicity in cortical culture. J Neurosci 10:693-705.

Lampert PW (1967) A comparative electron microscopic study of reactive, degenerating, regenerating, and dystrophic axons. J Neuropathol Exp Neurol 26:345-368.

Liu D, Thangnipon W, McAdoo DJ (1991) Excitatory amino acids rise to toxic levels upon impact injury to the rat spinal cord. Brain Res 547:344-348.

Martin LJ, Blackstone CD, Levey AI, Huganir RL, Price DL (1993) AMPA glutamate receptor subunits are differentially distributed in rat brain. Neuroscience 53:327-358.

Matute C, Miledi R (1993) Neurotransmitter receptors and voltagedependent $\mathrm{Ca}^{2+}$ channels encoded by mRNA from the adult corpus callosum. Proc Natl Acad Sci USA 90:3270-3274.

Matute C, Sanchez-Gomez MV, Martinez-Millan L, Miledi R (1997) Glutamate receptor-mediated toxicity in optic nerve oligodendrocytes. Proc Natl Acad Sci USA 94:8830-8835.

McDonald JW, Althomsons SP, Hyrc KL, Choi DW, Goldberg MP (1998) Oligodendrocytes from forebrain are highly vulnerable to AMPA/kainate receptor-mediated excitotoxicity. Nat Med 4:291-297.

McTigue DM, Horner PJ, Stokes BT, Gage FH (1998) Neurotrophin-3 and brain-derived neurotrophic factor induce oligodendrocyte proliferation and myelination of regenerating axons in the contused adult rat spinal cord. J Neurosci 18:5354-5365.

Noble LJ, Wrathall JR (1985) Spinal cord contusion in the rat: morphometric analyses of alterations in the spinal cord. Exp Neurol 88:135-149.

Noble LJ, Wrathall JR (1989) Correlative analyses of lesion development and functional status after graded spinal cord contusive injuries in the rat. Exp Neurol 103:34-40.

Oka A, Belliveau MJ, Rosenberg PA, Volpe JJ (1993) Vulnerability of oligodendroglia to glutamate: pharmacology, mechanisms, and prevention. J Neurosci 13:1441-1453.

Panjabi MM, Wrathall JR (1988) Biomechanical analysis of experimental spinal cord injury and functional loss. Spine 13:1365-1370.
Panter SS, Yum SW, Faden AI (1990) Alteration in extracellular amino acids after traumatic spinal cord injury [see comments]. Ann Neurol 27:96-99.

Peters A, Palay SL, Webster HD (1991) The fine structure of the nervous system. New York: Oxford UP.

Raines A, Dretchen KL, Marx K, Wrathall JR (1988) Spinal cord contusion in the rat: somatosensory evoked potentials as a function of graded injury. J Neurotrauma 5:151-160.

Ramon-Cueto A, Plant GW, Avila J, Bunge MB (1998) Long-distance axonal regeneration in the transected adult rat spinal cord is promoted by olfactory ensheathing glia transplants. J Neurosci 18:3803-3815.

Rosenberg LJ, Wrathall JR (1997) Quantitative analysis of acute axonal pathology in experimental spinal cord contusion. J Neurotrauma 14:823-838.

Sheardown MJ, Nielsen EO, Hansen AJ, Jacobsen P, Honore T (1990) 2,3-Dihydroxy-6-nitro-7-sulfamoyl-benzo $(F)$ quinoxaline: a neuroprotectant for cerebral ischemia. Science 247:571-574.

Shuman SL, Bresnahan JC, Beattie MS (1997) Apoptosis of microglia and oligodendrocytes after spinal cord contusion in rats. J Neurosci Res 50:798-808.

Sykova E, Svoboda J, Simonova Z, Jendelova P (1992) Role of astrocytes in ionic and volume homeostasis in spinal cord during development and injury. Prog Brain Res 94:47-56.

Tachibana M, Wenthold RJ, Morioka H, Petralia RS (1994) Light and electron microscopic immunocytochemical localization of AMPAselective glutamate receptors in the rat spinal cord. J Comp Neurol 344:431-454.

Tator CH, Fehlings MG (1991) Review of the secondary injury theory of acute spinal cord trauma with emphasis on vascular mechanisms [see comments]. J Neurosurg 75:15-26.

Teng YD, Wrathall JR (1997) Local blockade of sodium channels by tetrodotoxin ameliorates tissue loss and long-term functional deficits resulting from experimental spinal cord injury. J. Neurosci. 17:4359-4366.

Wrathall JR, Pettegrew RK, Harvey F (1985) Spinal cord contusion in the rat: production of graded, reproducible, injury groups. Exp Neurol 88:108-122.

Wrathall JR, Bouzoukis J, Choiniere D (1992a) Effect of kynurenate on functional deficits resulting from traumatic spinal cord injury. Eur J Pharmacol 218:273-281.

Wrathall JR, Teng YD, Choiniere D, Mundt DJ (1992b) Evidence that local non-NMDA receptors contribute to functional deficits in contusive spinal cord injury. Brain Res 586:140-143.

Wrathall JR, Choiniere D, Teng YD (1994) Dose-dependent reduction of tissue loss and functional impairment after spinal cord trauma with the AMPA/kainate antagonist NBQX. J Neurosci 14:6598-6607.

Wrathall JR, Teng YD, Choiniere D (1996) Amelioration of functional deficits from spinal cord trauma with systemically administered NBQX, an antagonist of non-N-methyl-D-aspartate receptors. Exp Neurol 137:119-126.

Wrathall JR, Teng YD, Marriott R (1997) Delayed antagonism of AMPA/kainate receptors reduces long-term functional deficits resulting from spinal cord trauma. Exp Neurol 145:565-573.

Wrathall JR, Li W, Hudson LD (1998) Myelin gene expression after experimental contusive spinal cord injury. J Neurosci 18:8780-8793.

Young W (1993) Secondary injury mechanisms in acute spinal cord injury. J Emerg Med 1:13-22. 